\title{
Nitrogen and Organic Matter Mineralization in the Tunisian Cork Oak Forest: A Laboratory Study
}

\author{
Zouaoui Ikbel1,2, Abbes Chaabane1, Ouled Sghaier Wided1, Hasnaoui Foued1, \\ Hasnaoui Brahim1, Smiti Samira² \\ ${ }^{1}$ Sylvo Pastoral Institute of Tabarka, University of Jendouba, Jendouba, Tunisia \\ ${ }^{2}$ Faculty of Sciences of Tunis, University of Tunis El Manar, Tunis, Tunisia \\ Email: zouaoui.ikbel@gmail.com
}

Received 16 February 2015; accepted 14 March 2015; published 19 March 2015

Copyright (C) 2015 by authors and Scientific Research Publishing Inc.

This work is licensed under the Creative Commons Attribution International License (CC BY).

http://creativecommons.org/licenses/by/4.0/

(c) (i) Open Access

\begin{abstract}
The mineralization of the organic matter is a very important phenomenon which leads to the release of nutriments used by plants. The rate of transformation of the organic matter depends on several factors and parameters such as climatic factors and biological and physicochemical properties of the soil and the litter. In this study, we investigate the effect of the addition of litter of various species as well as the effect of soil moisture on mineralization of organic matter and on mineral nitrogen release in three soils sampled in three cork oak stands during a period of 41 days under the same laboratory conditions. Carbon mineralization was determined using $\mathrm{CO}_{2}$ respiration method, whereas the mineral nitrogen content was measured at the last day of incubation both in soil samples with added plant leaf material, and in control soil samples without addition under two treatments of moisture $(40 \%$ and $80 \%$ WHC-water holding capacity). Our results show that the addition of leaf litter causes an increase in the microbial activity. Soils without addition were significantly different from the plant leaf added soils in respect to carbon mineralization at the end of the incubation period. Moreover, it is noted that the mineralization of carbon is more marked with moisture at $80 \%$ than that of $40 \%$, contrary to that of the nitrogen, which is not influenced by the variation of moisture.
\end{abstract}

\section{Keywords}

Mineralization, Organic Matter, Carbon, Nitrogen, Cork Oak, Moisture

\section{Introduction}

Foliar litter is the main input of organic carbon into forest soils. Its decomposition is one of the most important

How to cite this paper: Ikbel, Z., Chaabane, A., Wided, O. S., Foued, H., Brahim, H., \& Samira, S. (2015). Nitrogen and Organic Matter Mineralization in the Tunisian Cork Oak Forest: A Laboratory Study. Open Journal of Forestry, 5, 287-295. 
processes that determine the amount of organic C remaining in the forest floor (Berg et al., 2001). Thus, Litter decomposition process represents an essential phase in the organic matter and nutrient cycle. The litter decay rate is a factor that largely determines forest soil fertility and its regulation plays an important role in ecosystem functioning (Swift et al., 1979).

Decomposition rate of plant materials and nutrient release patterns are controlled by both biotic and abiotic factors; one of the most important is the litter quality (Aerts, 1997; Silver and Miya, 2001; Teklay et al., 2007). The initial concentrations of nitrogen $(\mathrm{N})$, phosphorus $(\mathrm{P})$, the ratios of $\mathrm{C} / \mathrm{N}$ and lignin/ $\mathrm{N}$ are generally recognized as the main litter quality variables controlling rates of decomposition (Melillo et al., 1982; Aerts and De Caluwe, 1997; Teklay et al., 2007). In this sense, the carbon-nitrogen ratio (C/N) has been demonstrated to be a good index of the susceptibility of litter to be degraded (Berg et al., 1982; Taylor et al., 1989). In general, litter with a low $\mathrm{C} / \mathrm{N}$ ratio is decomposed faster than litter with a high $\mathrm{C} / \mathrm{N}$ ratio (Adams and Atwill, 1982). However, when $\mathrm{C} / \mathrm{N}$ ratios exceed 75 - 100, other indexes such as lignin/ $\mathrm{N}$ may be better as indicators of litter quality (Heal et al., 1997).

The mineralization of the organic matter in the soil is a biological process that is influenced by the environmental conditions, mainly the temperature and moisture. On the one hand, temperature controls the enzymatic activity of soil microorganisms. On the other hand, soil water content is an important factor that may limit the microbial activity. N'Dayegamiye (2007) stresses that the activity of the microorganisms decreases under dry soil conditions. The activity of microorganisms is also closely associated with nutrient availability, as well as with soil aeration as it controls the diffusion of oxygen in the soil. These factors affect the soil microbial community simultaneously and cannot be separated from each other (Griffin, 1981). The microorganisms are generally considered as being a driving force or a catalyst of the decomposition process. Indeed, they break up the organic matter in order to obtain essential energy for their growth and their activity.

Grundmann et al. (1995) and Uhlirova et al. (2005) have shown that the optimum soil moisture for aerobic microbial processes is 50\% - 60\% of WHC (soil water holding capacity). At soil moistures below this optimum, low water and nutrient availability limit microbial processes, while at water contents above this optimum, microbial aerobic activity is limited by reduced aeration (Papendick and Campbell 1981) and development of anaerobic conditions. Until a certain limit, the biological activities and the rates of mineralization increase with the rise in temperature and moisture in the soil.

The organic matter in contact with the soil undergoes a disintegration of its components. The microorganisms of the soil carry out this primarily biological stage. In the soil, the litter is subjected to two great types of processes. A part is mineralized, thus closing the $\mathrm{C}$ and $\mathrm{N}$ cycles, while the other part, is preserved in the soil and constitutes the humus. Nitrogen and carbon fluxes are closely dependent during the decomposition of litter (Mary et al., 1996). During the decomposition process, carbon is used as energy substrate by the microorganisms and is integrated into the microbial biomass (organization) while the most recalcitrant part, can be stabilized after a period of time (Berg et al., 1982). Moreover, in forest soils, $\mathrm{N}$ mineralization of soil organic matter is an important mechanism as it is the main source of mineral $\mathrm{N}$ in these ecosystems.

Mediterranean forests are subject to very restrictive conditions such as frequent drought conditions, higher temperatures and forest management practices that degrade the soil especially in the south part of the Mediterranean basin. Little has been investigated about soil C, N and microbial dynamics on organic matter decomposition rates in such Mediterranean ecosystems. The overall objective of this study was to provide information about carbon and nitrogen mineralization in North of Africa especially in Tunisia. For this reason, we will examine the effects of the variation of the soil water content and the addition of leaf litter on organic matter and nitrogen mineralization under the same laboratory conditions. This was achieved in three contrasting cork oak forests representative of one of the main forest ecosystems in the south part of the Mediterranean basin. Indeed, cork oak in Tunisia occupies a surface that represents approximately $50 \%$ of the area occupied by deciduous forests and approximately $10 \%$ of the total forest area in Tunisia and about $5 \%$ of the area occupied by the world cork oak forests. In Tunisia, cork oak forests are at $80 \%$ in pure stands and at 20\% mixed with zeen oak (Quercus canariensis Willd). In addition to their important hydrological and ecological roles, cork oak forests are subject to intense economic exploitation placing Tunisia among major cork producing countries.

\section{Materials and Methods}

\subsection{Study Sites}

Soils used for the incubation experiment were sampled from three sites in Tabarka, North-West of Tunisia (Lati- 
tude $36^{\circ} 52^{\prime} 57.83^{\prime \prime N} /$ Longitude $8^{\circ} 46^{\prime} 52.48^{\prime \prime E}$ ). The climate of study sites is Mediterranean and Tabarka be longs to the humid bioclimatic zone. The annual precipitation is $1034 \mathrm{~mm}$. The wettest season is winter with a maximum of $176.2 \mathrm{~mm}$ in December followed by November with $157.6 \mathrm{~mm}$. The driest season is summer with a minimum in July $4.9 \mathrm{~mm}$ followed by the month of August $11.2 \mathrm{~mm}$. The mean annual temperature is $18.5^{\circ} \mathrm{C}$ (Selmi, 1985; Hasnaoui, 1992).

The three sites used for soil sampling are described below and in Table 1. Site 1, called hereafter S1 is composed of a pure vegetation of cork oak (Quercus suber L). Site 2 (S2) is composed of a mixed vegetation of cork oak and zeen oak (Quercus canariensis willd). Site 3 (S3) is composed of a degraded vegetation of cork oak. Soils in S1 and S2 have essentially the same chemical characteristics, but soil in S3 presents carbon and nitrogen contents lower than the two others (Table 1).

\subsection{Experimental Design}

The effects of soil moisture and leaf litter addition on nitrogen and organic matter mineralizationwere studied by incubation under aerobic conditions. This experiment was established following a full factorial design: 4 replicates with 4 leaf litter types (Quercus suber (Qs), Quercus canariensis Willd (Qc), Pinus pinaster (Pp) and Pinus pinea (Ppinea)) and 2 controlled soil moistures ( $80 \%$ and $40 \%$ WHC) in three study sites.

The soil sampling in the three forests was carried out in October 2006. Five superficial soil samples were taken from the upper $20 \mathrm{~cm}$ of each forest after removing litter and debris from the surface and then were mixed, homogenized and considered as a composite and representative samples of each site. These composite samples were oven dried at $30^{\circ} \mathrm{C}$ and sieved through a $2 \mathrm{~mm}$ mesh sieve before incubation.

Organic carbon content of soil was determined by the colorimetric method and organic nitrogen content (\%) was determined by kjeldahl method. Leaf litter was also collected at the same time, in 2006 from the same forest sites, they were oven dried at $70^{\circ} \mathrm{C}$ for $48 \mathrm{~h}$ and then passed through a $200 \mu \mathrm{m}$ mesh sieve. Main Chemical properties of the litter used for the incubation are shown in Table 2.

\subsection{Measurement of $\mathrm{C}$ and $\mathrm{N}$ Mineralization}

Carbon mineralization was measured as respired $\mathrm{CO}_{2}-\mathrm{C}$ in closed chamber. According the experimental design described above, $300 \mathrm{~g}$ of soils was mixed with $5 \mathrm{~g}$ oven-dried leaf and placed in $1000 \mathrm{ml}$ vessels for the carbon mineralization assays. The moisture contents of soils were adjusted to $80 \%$ of their field capacity. The same experience was realized with the moisture of $40 \% \mathrm{WHC}$. The $\mathrm{C}-\mathrm{CO}_{2}$ produced from microbial respiration was trapped periodically in $8 \mathrm{ml} \mathrm{NaOH}$ solutions in a small tube. Empty vessel was used as blank. The $\mathrm{C}_{-} \mathrm{CO}_{2}$ pro-

Table 1. Main physical and chemical properties (mean \pm SE Standard Error, $n$ $=3$ ) of the soils sampled from the three cork oak forest sites.

\begin{tabular}{cccc}
\hline Characteristic & Site 1 & Site 2 & Site 3 \\
\hline $\mathrm{pH}$ & $5.28 \pm 0.11$ & $5.18 \pm 0.07$ & $5.58 \pm 0.12$ \\
$\mathrm{C}(\%)$ & $10.27 \pm 3.6$ & $7.71 \pm 3.05$ & $1.66 \pm 1.26$ \\
$\mathrm{~N}(\%)$ & $2 \pm 0.3$ & $1.25 \pm 0.2$ & $0.5 \pm 0.11$ \\
C/N ratio & $5.13 \pm 1.1$ & $6.17 \pm 1.09$ & $3.32 \pm 0.9$ \\
\hline
\end{tabular}

Table 2. Chemical properties of the initial quality of litter used in the experimental work.

\begin{tabular}{cccccc}
\hline Litter type & C (\%) & N (\%) & C/N (\%) & Lignin (\%) & Lignin/N (\%) \\
\hline Pinus pinea & 27.7 & 1.08 & 25.55 & 17.23 & 15.95 \\
Quercus suber & 32.28 & 0.98 & 32.95 & 19.43 & 19.83 \\
Quercus canariensis & 27.59 & 1.72 & 16.04 & 18.70 & 10.87 \\
Pinus pinaster & 38.15 & 0.7 & 54.51 & 17.63 & 24.83 \\
\hline
\end{tabular}


duced as a result of microbial respiration was measured about every 3 days by titration with chlorhydric acid $\mathrm{HCl}$. Incubations were carried out for 41 days at non-limiting temperature ranging from $20^{\circ} \mathrm{C}$ to $25^{\circ} \mathrm{C}$. Net $\mathrm{C}-\mathrm{CO}_{2}$ production from litter decomposition at each sampling time was determined as the difference between cumulative $\mathrm{C}-\mathrm{CO}_{2}$ produced by soil + litter and by soil alone, and then the ratio (\%) of carbon mineralization of the three soils was calculated by diving the cumulative $\mathrm{C}-\mathrm{CO}_{2}$ produced in 41 days by the $\mathrm{C}$ added.

Nitrogen mineralization was calculated at the end of the incubation period. For this, $5 \mathrm{~g}$ of soil was mixed with $25 \mathrm{ml} \mathrm{KCl} \mathrm{(1N)} \mathrm{solution} \mathrm{and} \mathrm{shaken} \mathrm{for} 1 \mathrm{~h}$. Mineral nitrogen was measured using specific ion meter (Thermo-ORION 710).

\subsection{Statistical Analysis}

Data analysis was performed using SAS software. Statistical significance of differences between means of different variables has been determined bythe Student Newman Keuls (SNK) test using a significance threshold of $5 \%$. We tested the effect of litter, sites and soil moisture on carbon and nitrogen mineralization.

\section{Results}

Statistical tests show a highly significant effect $(P<0.0001)$ of soil moisture, type of soil, addition of fresh litter and the incubation time on the soil respiration (Table 3 ). The cumulative quantity of $\mathrm{C}-\mathrm{CO}_{2}$ produced clearly increased with the incubation time in all treatments $(P<0.0001)$. There were also significant differences in the quantity of $\mathrm{C}$ mineralized between the litters and the two moisture treatments at the end of the incubation period $(P<0.0001$, Table 3$)$. No double or triple interaction was reported.

\subsection{Moisture Effect}

The moisture of samples plays an important role in $\mathrm{C}$ mineralization. Indeed, the increase in moisture causes an increase in carbon mineralization (Figure 1). The kinetics of mineralization is much more important at a moisture content of $80 \%$ of field capacity than $40 \%$ and that for the 3 sites $(P<0.0001)$, (Figure 1 ). Thus, after 41 days of incubation, the average of the soil respiration over all plots and litter treatments decreases from 23.23 mg C- $-\mathrm{CO}_{2}$ at the moisture of $80 \%$ WHC to $21.72 \mathrm{mg} \mathrm{C}-\mathrm{CO}_{2}$ at the moisture of $40 \%$ WHC.

\subsection{Effect of Soil's Type and Litter Addition on C Mineralization}

Statistical analysis shows that there is a significant effect $(P<0.0001)$ of soil type on $C$ mineralization (Table 3$)$. In fact, our study shows that the S1 and S2 have the higher activity of $\mathrm{C}$ mineralization. This activity reached after 41 days of incubation, respectively an average of 24.03 and $23.13 \mathrm{mg} \mathrm{C}-\mathrm{CO}_{2}$. However, this activity is lower in the S3 (20.28 mg C-CO ${ }_{2}$ (Figure 2).

Generally, cumulative $\mathrm{C}$ mineralization of soil amended with plant residues was significantly higher than the control during the entire incubation period.

On the one hand, our results suggest that the addition of leaves to the three types of soil clearly increases microbial activity (Figure 3 and Figure 4). However, there has been a latency period ranging from 3 to 5 days depending on the nature of soil and the type of litter. The difference between the different types of litter was observed clearly after 20 to 30 days of incubation, depending on the type of soil and the moisture.

After 41 days of incubation, the decomposition of Pinu spinea needles in the S1 and S2 at 80\% WHC was the fastest and higher than the others while the decomposition of Pinus pinaster was lower than the other litters in

Table 3. Variance analysis of the effect of incubation time, addition of leaf litter and moisture on the rate of $\mathrm{C}$ mineralized.

\begin{tabular}{cccc}
\hline & df & F & Significance \\
\hline Incubation time & 8 & 1154.79 & $<0.0001^{* * *}$ \\
Moisture & 1 & 18.38 & $<0.0001^{* * *}$ \\
Sites & 2 & 51.33 & $<0.0001^{* * *}$ \\
litter & 4 & 47.89 & $<0.0001^{* * *}$ \\
\hline
\end{tabular}




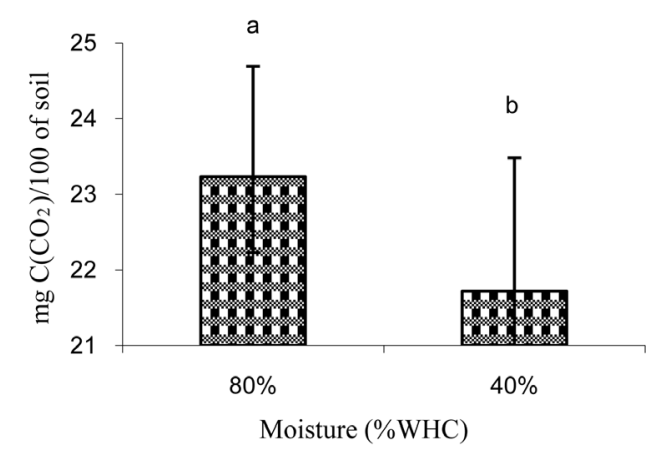

Figure 1. Effect of soil moisture (\% WHC-water holding capacity) (soils plots and litter treatments were pooled) on total amount of respired $\mathrm{CO}_{2}$ (mg C- $\mathrm{CO}_{2} / 100 \mathrm{~g}$ of soil). Vertical bars are standard deviations.

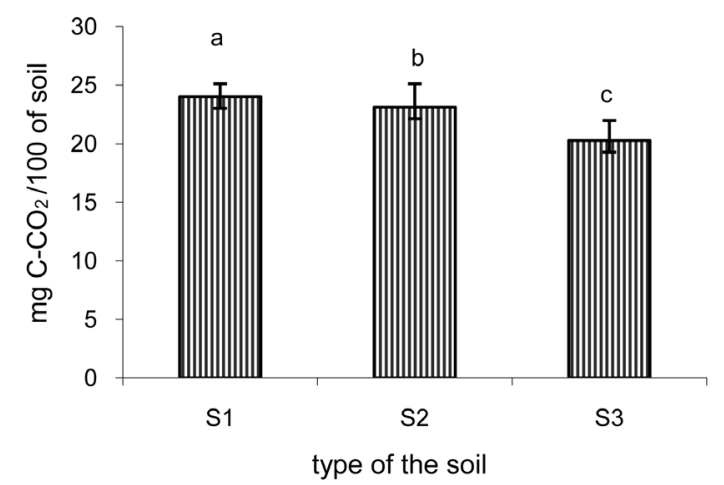

Figure 2. Total amount of respired $\mathrm{CO}_{2}$ (mg C-CO$/ 100 \mathrm{~g}$ of soil) in the different sites. Vertical bars are standard deviations.

the three sites and at the two moisture treatments (Figure 3 and Figure 4). On the other hand, the decomposition of Quercus canariensis is higher than Pinus pinea needles in site S1 and S3 at 40\% WHC.

\subsection{Ratio of $\mathrm{C}$ and $\mathrm{N}$ Mineralization}

The ratio of carbon mineralization was not statistically affected by moisture content, soil's type and the addition of litter. In addition, neither was there any significant effect of double and triple interactions (Table 4). The ratio of mineralized nitrogen was only affected by soil's type $(P<0.0001)$; this percentage was higher in S1 $(2.02 \%)$ and lower in site 3 (1.33\%) (Figure 5).

\section{Discussion}

The aim of our study was to provide information on carbon mineralization in North of Africa since little study on this subject has been conducted.

So, soil respiration is measured by the release of carbon dioxide $\left(\mathrm{C}-\mathrm{CO}_{2}\right)$ that is removed from the soil as a result of the decomposition of organic matter by microorganisms. The results obtained in this work can suggest that the addition of leaf litter from different plant species to the three type of soil clearly increases microbial activity. In addition, we found that moisture plays an important role in the carbon mineralization. Indeed, we note that a relatively high humidity ( $80 \%$ of field capacity) promotes microbial activity under the three different sites.

However, this activity decreases as the soil dries out (Figure 1). Results obtained in this study are also in agreement with previous studies (Azzalini \& Diggle, 1993) that show that the amount of $\mathrm{CO}_{2}$ released from the soil increases with the increase of moisture until saturation. At the saturation point, microbial activity is inhibited by low aeration of the soil and therefore by the lack of available oxygen. The addition of litter causes an increase in microbial activity in the three sites studied, since the content of $\mathrm{C}-\mathrm{CO}_{2}$ released from soils without addition is quite low compared to other soils supplemented with litter (Aka et al., 2005). 
Table 4. Effect of moisture, type of soil and leaf litter addition on the variation of the ratio of carbon mineralization to added carbon and the ratio of $\mathrm{N}$ mineralization to total nitrogen content of litter at the end of incubation period.

\begin{tabular}{ccccc}
\hline & & df & F & Significance \\
\hline \multirow{2}{*}{ Ratio of mineralization } & Moisture & 1 & 3.31 & 0.0710 \\
(\% of C added) & Type of soil & 2 & 1.05 & 0.3507 \\
& Litter & 4 & 1.44 & 0.1741 \\
\multirow{2}{*}{ Ratio of N mineralization } & Moisture & 1 & 0.08 & 0.72 \\
& Type of soil & 2 & 1.98 & $<0.0001^{* * *}$ \\
& Litter & 4 & 2.58 & 0.09 \\
\hline
\end{tabular}

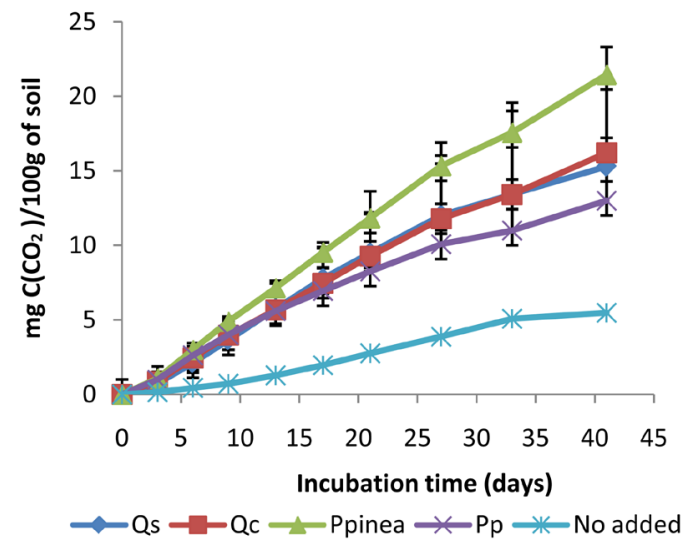

(a)

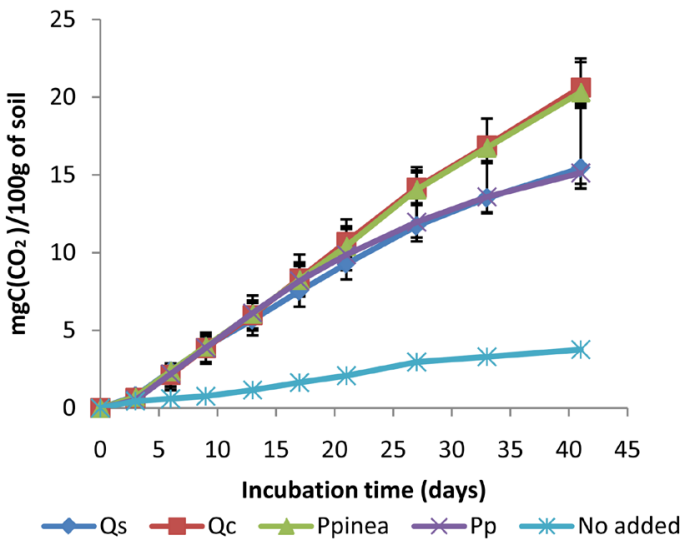

(b)

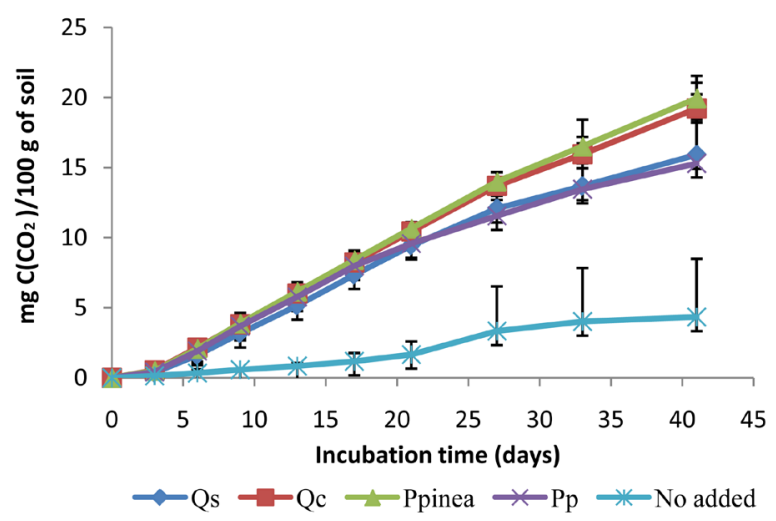

(c)

Figure 3. Cumulative $\mathrm{C}$ mineralized in the soils under (a) site 1, (b) site 2 and (c) site 3 at different days at the soil moisture of $80 \%$ WHC (water holding capacity). Vertical bars are standard deviation.

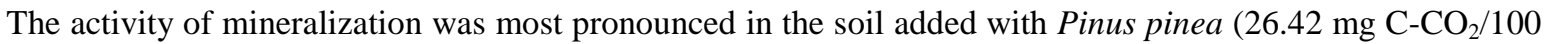
g), Quercus canariensis (25.11 mg C-CO $2 / 100 \mathrm{~g}$ ), and Quercus suber (23.27 $\mathrm{mg} \mathrm{C-CO} / 100 \mathrm{~g}$ ); but the evolution of the $\mathrm{C}-\mathrm{CO}_{2}$ in the three soils added with Pinus pinaster litter at the end of the incubation period was weak and slow compared with other litters. This could be explained by the fact that the needles of this species have a certain inability to be decomposed because these needles have a very long half-life of 5.4 years, while the Quercus canariensis is 4.96 years (Selmi, 1985; Kurz et al. 2000) and also because of the very high percentage of $\mathrm{C} / \mathrm{N}$ ratio of the litter $(\mathrm{C} / \mathrm{N}=54.51)$.

Van Wesemael (1993) also suggested that in the Mediterranean forest in southern toskany (Italy), the decomposition of deciduous oak was most rapid than sclerophyllous oak (Quercus suber) and the decomposition rate of the pine needles ( Pinus pinaster ) in the coniferous forest was much lower. 


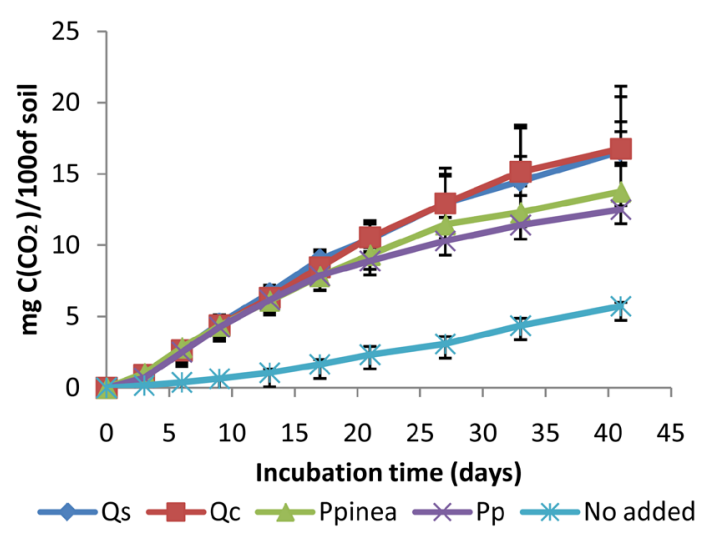

(a)

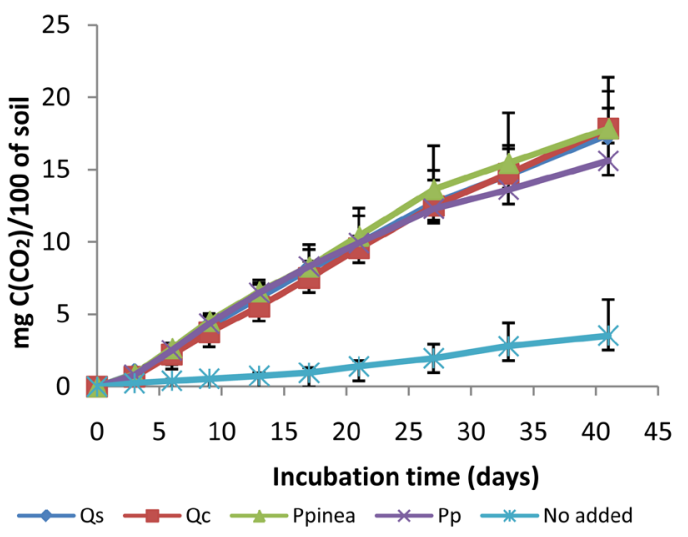

(b)

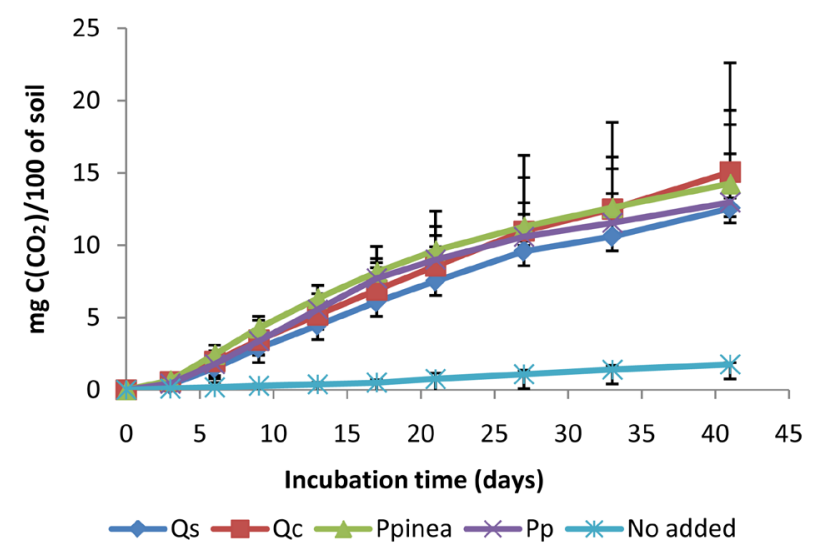

(c)

Figure 4. Cumulative $\mathrm{C}$ mineralized in the soils under (a) Site 1, (b) Site 2 and (c) Site 3 at different days at the soil moisture of $40 \%$ WHC (water holding capacity). Vertical bars are standard deviation.

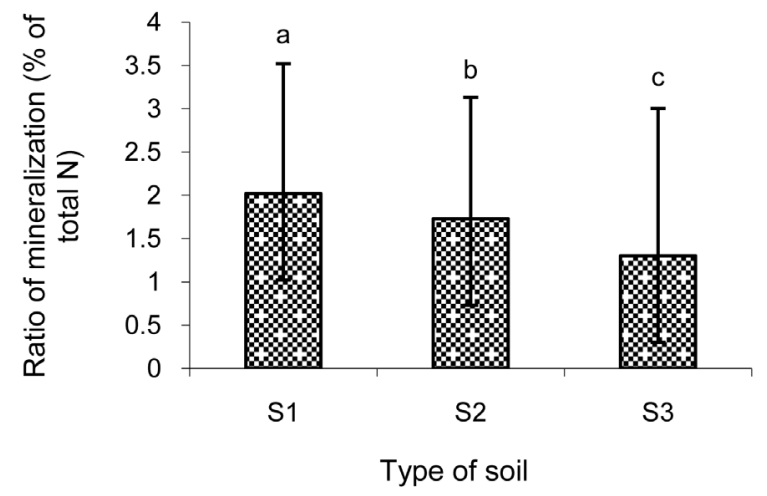

Figure 5. Ratio of mineralization of the organic nitrogen in Site 1 (a), Site 2 (b) and Site 3 (c) at the end of incubation period.

This was confirmed for Pinus pinaster litter but it was the opposite for Pinus pinea.

In our study, we concluded that the decomposition showed negative correlation with initial lignin content as well as $\mathrm{C} / \mathrm{N}$ and lignin/N (Table 2). Some studies revealed that lignin concentration largely explained the litter decomposition within and between species (McTiernan et al., 2003; Osono, T. and Takeda, H., 2005).

Pinus pinea and Quercus canariensis with the highest initial N concentration and the lowest C/N and lignin/N ratio decompose faster than other individual residues over the incubation period. There is a strong correlation among $\mathrm{N}$ concentrations, the $\mathrm{C} / \mathrm{N}$ or lignin/ $\mathrm{N}$ ratio and $\mathrm{C}$ mineralization in our study. 
E. F. Salamanca et al. found that Quercus showed a higher decomposition than Pinus litter because the initial substrate quality, that's the nitrogen, was higher in Quercus than that in Pinus leaf litter.

Previous studies also suggested that initial $\mathrm{N}$ concentration or $\mathrm{C} / \mathrm{N}$ ratio of residues was the main factor controlling decomposition and nutrient release (Melillo et al., 1982; Berg, 1986; Taylor et al., 1989; Raiesi, 2006; Teklay et al., 2007).

Also, nitrogen exerts great influence in the early stage of decomposition because it affects the physiological adaptation of decomposer organisms (Richards, 1987), and leaf litter with higher initial N concentration (lower C:N ratio) decomposes faster (Berg and Staaf, 1982).

At the end of the incubation period, the percentage of nitrogen mineralization showed that the mineralization process was higher in S1 and S2 but lower in S3. These results showed that microbial activity was much more intense in the first two soils. In comparison with control samples, we notice that the rate of mineralization increases with the addition of litter. Our results contradict those found by Aka and Darici (2005), who found that the percentage of mineralization decreased with the addition of Aleppo pine and oak Kermes litter in different type of soil. According to these findings, stimulatory or inhibitory effects of organic matter addition to soil microbial activity may depend on internal conditions of soils.

\section{Acknowledgements}

We are very grateful for the thorough and helpful comments from the reviewer of the manuscript. We also thank all the people who helped us during field and laboratory measurements. Finally, we would like to thank Dr Kamel Soudani for his critical and thoughtful comments and for his time spent in preparing our manuscript.

\section{References}

Adams, M. A., \& Atwill, P. M. (1982). Nitrogen Mineralization and Nitrate Reduction in Forests. Soil Biology and Biochemistry, 14, 197-202. http://dx.doi.org/10.1016/0038-0717(82)90023-2

Aerts, R. (1997). Climate, Leaf Litter Chemistry and Leaf Litter Decomposition in Terrestrial Ecosystems: A Triangular Relationship. Oikos, 79, 439-449.

Aerts, R., \& De Caluwe, H. (1997). Initial Litter Respiration as Indicator for Long-Term Leaf Litter Decomposition of Carex Species. Oikos, 80, 353-361. http://dx.doi.org/10.2307/3546603

Aka, H., \& Darici, C. (2005). Carbon and Nitrogen Mineralization in Carob Soils with Kermes Oak and Aleppo Pine Leaf Litter. Soil Biology, 41, 31-38.

Azzalini, A., \& Diggle, P. (1993). Prediction of Soil Respiration Rates from Temperature, Moisture Content and Soil Type. J. STOR, Applied Statistics, 43, 505-526.

Berg B., Mc Claugherty, C., De Santo, A. V. et al. (2001). Johnson, Humus Buildup in Boreal Forests: Effects of Litter Fall and Its N Concentration. Canadian Journal of Forest Research, 31, 988-998. http://dx.doi.org/10.1139/x01-031

Berg, B., Staaf, H.,Wessen, B., \& Ekbohm, G. (1982). Nitrogen Level and Decomposition in Scots Pine Needle Litter. Oikos, 38, 291-396. http://dx.doi.org/10.2307/3544667

Griffin, D. M. (1981). Water and Microbial Stress. Advances in Microbial Ecology, 5, 91-136.

Grundmann, G. L., Renault, P., Rosso, L., \& Bardin, R. (1995). Differential Effects of Soil Water Content and Temperature on Nitrification and Aeration. Soil Science Society of America Journal, 59, 1342-1349. http://dx.doi.org/10.2136/sssaj1995.03615995005900050021x

Hasnaoui, B. (1992). Chênaies du Nord de la Tunisie, Ecologie et Régénération. Doctorat d’état es-Sciences Naturelles, Univ de Provence Aix Marseille I, 186 p.

Heal, O. W., Anderson, J. M., \& Swift, M. J. (1997). Plant Litter Quality and Decomposition: An Historical Overview. In G. Cadisch, \& K. E. Giller (Eds.), Driven by Nature: Plant Litter Quality and Decomposition (pp. 3-30). Wallingford: CAB International.

Kurz, D. C., Coûteaux, M. M., \& Thiéry, J. M. (2000). Residence Time and Decomposition Rate of Pinus Pinaster Needles in a Forest Floor from Direct Field Measurements under a Mediterranean Climate. Soil Biology and Biochemistry, 32, 1197-1206. http://dx.doi.org/10.1016/S0038-0717(00)00036-5

Mary, B., Recous, S., Darwis, D., \& Robin, D. (1996). Interactions between Decomposition of Plant Residues and Nitrogen Cycling in Soil. Plant and Soil, 181, 71-82. http://dx.doi.org/10.1007/BF00011294

McTiernan, K. B., Couteaux, M. M., Berg, B., Berg, M. P., de Anta, R. C. et al. (2003). Changes in Chemical Composition of Pinus sylvestris Needle Litter during Decomposition along a European Coniferous Forest Climate Transect. Soil Biolo- 
gy and Biochemistry, 35, 801-812. http://dx.doi.org/10.1016/S0038-0717(03)00107-X

Melillo, J. M., Aber, J. D., \& Muratore, J. F. (1982). Nitrogen and Lignin Control of Hardwood Leaf Litter Decomposition Dynamics. Ecology, 63, 621-626. http://dx.doi.org/10.2307/1936780

N’Dayegamiye, A. (2007). La contribution en azote du sol reliée à la minéralisation de la matière organique: Facteur climatique et régies agricoles influençant les taux de minéralisation d'azote. Colloque sur l'azote, CRAAQ-OAQ.

Osono, T., \& Takeda, H. (2005). Limit Values for Decomposition and Convergence Process of Lignocellulose Fraction in Decomposing Leaf Litter of 14 Tree Species in a Cool Temperate Forest. Ecological Research, 20, 51-58.

http://dx.doi.org/10.1007/s11284-004-0011-z

Papendick, R. I., \& Campbell, G. S. (1981). Theory and Measurement of Water Potential. L.F, 1-22.

Raiesi, F. (2006). Carbon and N Mineralization as Affected by Soil Cultivation and Crop Residue in a Calcareous Wetland Ecosystem in Central Iran. Agriculture, Ecosystems \& Environment, 112, 13-20.

http://dx.doi.org/10.1016/j.agee.2005.07.002

Richards, B. N. (1987). The Microbiology of Terrestrial Ecosystems (p. 399). Harlow: Longman.

Salamanca, E. F., Kaneko, N., \& Katagiri, S. (1998). Effects of Leaf Litter Mixtures on the Decomposition of Quercus serrata and Pinus densiflora Using field and Laboratory Microcosm Methods. Ecological Engineering, 10, 53-73. http://dx.doi.org/10.1016/S0925-8574(97)10020-9

Selmi, M. (1985). Différenciation des sols et fonctionnement des écosystèmes forestiers sur grés numidien de Kroumirie (Tunisie). Ecologie de la Subéraie-Zeenaie. Doctorat d’état es-Sciences Naturelles, Univ de Nancy I, 200 p.

Silver, W. L., \& Miya, R. K. (2001). Global Patterns in Root Decomposition: Comparisons of Climate and Litter Quality Effects. Oecologia, 129, 407-419. http://dx.doi.org/10.1007/s004420100740

Swift, M. J., Heal, O., \& Anderson, J. (1979). Decomposition in Terresterial Ecosystems (Studies in Ecology 5, p. 372). Oxford: Blackwell Scientific Publication.

Taylor, B. R., Parkinson, D., \& Parsons, W. F. J. (1989). Nitrogen and Lignin Content as Predictors of Litter Decay Rates: A Microcosm Test. Ecology, 70, 97-104. http://dx.doi.org/10.2307/1938416

Teklay, T., Nordgren, A., Nyberg, G., \& Malmer, A. (2007). Carbon Mineralization of Leaves from Four Ethiopian Agroforestry Species under Laboratory and Field Conditions. Applied Soil Ecology, 35, 193-202. http://dx.doi.org/10.1016/j.apsoil.2006.04.002

Uhlirova, E., Elhottova, D., Triska, J., \& Santruckova, H. (2005). Physiology and Microbial Community Structure in Soil at Extreme Water Content. Folia Microbiologica, 50, 161-166. http://dx.doi.org/10.1007/BF02931466

Van Wesemael, B. (1993). Litter Decomposition and Nutrient Distribution in Humus Profiles in Some Mediterranean Forests in Southern Tuscany. Forest Ecology and Management, 57, 99-114. http://dx.doi.org/10.1016/0378-1127(93)90165-J 